Research, part of a Special Feature on The influence of human demography and agriculture on natural systems in the Neotropics

\title{
Historical, Demographic, and Economic Correlates of Land-Use Change in the Republic of Panama
}

\author{
${\underline{\text { Stuart Joseph } \text { Wright }^{1}}}^{\text {and Mirna Julieta Samaniego }}{ }^{1}$
}

\begin{abstract}
The Republic of Panama recently experienced a limited forest transition. After five decades of decline, the total forest cover increased by $0.36 \% \mathrm{yr}^{-1}$ between 1992 and 2000; however, mature forest cover simultaneously decreased by $1.3 \% \mathrm{yr}^{-1}$. This limited forest transition at the national scale comprised two distinctly different patterns of recent forest-cover change related to historical land use. Districts that were largely deforested when the first national survey of forest cover was completed in 1947 experienced a strong forest transition between 1992 and 2000. In these, the proportion of the population employed in agriculture decreased by an average of $31 \%$ and natural secondary forest succession increased the total forest cover by an average of 85\% between 1992 and 2000. In contrast, no forest transition was evident for districts that were largely forested in 1947. In these, the absolute number of people employed in agriculture remained constant, old-growth forest cover decreased by $8 \%$ on average, and natural secondary forest succession increased, so that the total forest cover tended to be static between 1992 and 2000. Historical land use, an index of human poverty, and the population density of agricultural workers explained $61 \%$ of the among-district variation in forest cover in 2000 , with forest concentrated in areas where populations were small and poor. Historical land use and gross income per hectare from agriculture explained $23.5 \%$ of the among-district variation in forest-cover change between 1992 and 2000. The early history of forest loss, an uneven distribution of people, and disparities in farm income contributed to the limited forest transition observed in Panama.
\end{abstract}

Key Words: agricultural income; agriculture; cattle; deforestation; forest transition; land cover; pasture; plantation; reforestation; tropical forest

\section{INTRODUCTION}

Land-use and land-cover change (LULCC) contributes to human well-being through the products of new land use, to the global biodiversity crisis through the loss of natural habitats (Millenium Ecosystem Assessment 2005), and to global environmental change through altered surface albedo, hydrological cycles, and carbon sequestration (Meehl et al. 2007). A critical question for the future of global biodiversity and global climate concerns LULCC throughout the tropics (Millenium Ecosystem Assessment 2005, Wright and MullerLandau 2006, Meehl et al. 2007).

The time course of LULCC has varied widely among regions. The conversion of tropical forest to agriculture was underway in the $1700 \mathrm{~s}$, but increased exponentially after 1950 (Ramankutty and Foley 1999). The conversion of temperate forests to agriculture occurred earlier and was reversed after 1950 as the land area devoted to agriculture declined and forests were restored (Ramankutty and Foley 1999). The switch from net decreases to net increases in forest area has been described as the forest transition (Mather 1992).

In developed countries, forest transitions occurred as technological innovation increased agricultural yields, reduced the need for farm labor, and created jobs in urban centers that absorbed farmers displaced from agriculturally marginal land (Rudel et al. 2005). Today, it is far from clear that developing countries will follow this path (Klooster 2003, Perz and Skole 2003). Moreover, developed countries experienced a wide range of forest 
transitions (Rudel et al. 2005, Kauppi et al. 2006). Forest cover fell to $<5 \%$ of its pre-agricultural extent in China and several European countries before the establishment of tree plantations caused forest transitions. In contrast, forest cover never fell to $<25 \%$ in the United States or to $<50 \%$ in Canada and South Korea before natural secondary succession on abandoned land caused forest transitions. These contrasting forest transitions have very different implications for biodiversity conservation and carbon sequestration.

There is growing evidence for a similar diversity of forest transitions among tropical countries. At one extreme, the situation in Haiti demonstrates that forest transitions are not inevitable as forest cover approaches zero (Food and Agriculture Organization 2006). In contrast, forest transitions have already occurred in many tropical countries (Aide and Grau 2004, Food and Agriculture Organization 2006, Rudel et al. 2005, Hecht et al. 2006, Kauppi et al. 2006). These tropical forest transitions are as diverse as those observed among developed nations. Forest cover fell to $<5 \%$ in Puerto Rico and El Salvador, but was always $>30 \%$ in Costa Rica (Kleinn et al. 2002, Lugo and Helmer 2004, Hecht et al. 2006, Parés-Ramos et al. 2008). Increases in forest area were caused by tree plantations in Bangladesh and India and by secondary succession on abandoned land in Puerto Rico and Costa Rica (Kleinn et al. 2002, Lugo and Helmer 2004, Food and Agriculture Organization 2006).

The time course and causes of LULCC also vary spatially within countries (Grau et al. 2008, Killeen et al. 2008, Izquierdo et al. unpublished). Within Brazil for example, net deforestation continues in the Amazon (Neeff et al. 2006), whereas a forest transition occurred as early as 1975 in the Atlantic coastal forests of Santa Catarina (Baptista and Rudel 2006). Country-level studies obscure variation at smaller spatial scales. Subnational-level studies of LULCC are required to understand the causes of differences in forest transitions (Klooster 2003).

We used three open-access data sets to examine LULCC between 1992 and 2000 for the 76 districts that compose the Republic of Panama: the national agricultural census of 2000 , the decennial population censuses of 1990 and 2000, and land cover obtained from LandSat images in 1992 and 2000. We combined these data with historical information on land cover in 1947 to explore correlates of land cover in 2000 and land cover change between 1992 and 2000. We found two trajectories of land use within Panama. One trajectory was characterized by a robust forest transition, whereas the other was characterized by ongoing losses of mature forest and increases in secondary forest.

\section{The climate, history, and economy of Panama}

Forest is the potential vegetation of Panama, with the exception of tidal flats $\left(21 \mathrm{~km}^{2}\right)$, swamps $(337$ $\mathrm{km}^{2}$ ), and the peak of Vulcan Baru, which is above the tree line (Holdridge and Budowski 1956). Lowland temperatures average $25-27^{\circ} \mathrm{C}$ year round. Annual rainfall averages $3-4.5 \mathrm{~m}$ in the Caribbean lowlands, $1.2-2 \mathrm{~m}$ in most of the Pacific lowlands, and can be substantially greater along the central cordillera and in other mountainous areas. Rainfall is less seasonal in the Caribbean lowlands than in the Pacific lowlands, where monthly means are $<100 \mathrm{~mm}$ for $0-2$ months and 4-6 months, respectively. The wettest portions of the Pacific lowlands include Coiba Island, the southwestern Azuero Peninsula, and areas near Colombia, where Pacific climate systems increase the amount of rainfall (Schwerdtfeger 1976).

Estimates of the indigenous population before Spanish contact range from $2.5 \times 10^{5}$ to $2.0 \times 10^{6}$ (Sauer 1966, Jaén Suárez 1981). Spanish contact decimated these people, and the population recovered slowly from $2.5 \times 10^{4}$ in 1607 to $8.5 \times$ $10^{4}$ in 1790 and $3.15 \times 10^{5}$ in 1896 (Jaén Suárez 1981). Colonial agriculture focused on cattle and was restricted to the dry Pacific coastal plain. There were $1.1 \times 10^{5}$ cattle and horses in 1607 and $1.93 \times$ $10^{5}$ cattle in 1790 (Jaén Suárez 1981). Fig. 1 shows the founding dates of the oldest continuously occupied communities. The dry Pacific coastal plain was settled in the 16th century. With the exception of Caribbean ports that were essential for communication with Spain, the wetter portions of Panama were first settled in the 19th and 20th centuries or remain unsettled today.

A lack of infrastructure curtailed population and economic growth during four centuries of Spanish and Colombian rule (Heckadon Moreno 1984, Jaén Suárez 1981). As an example, public sanitation and medical facilities were absent; infant mortality was rampant because village midwives knew nothing of antiseptic measures; and malaria, diphtheria, syphilis, smallpox, measles, chicken pox, and 
Fig. 1. Map of the Republic of Panama showing district boundaries, areas forested in 1947, areas largely deforested in 1947, foundation dates of the first towns that have since been occupied continuously, and place names mentioned in the text. Spaniards settled the dry Pacific arc (most of the pale yellow area) in the 16th century. The remainder of the country was settled in the 19th and 20th centuries or remains in old-growth forest.

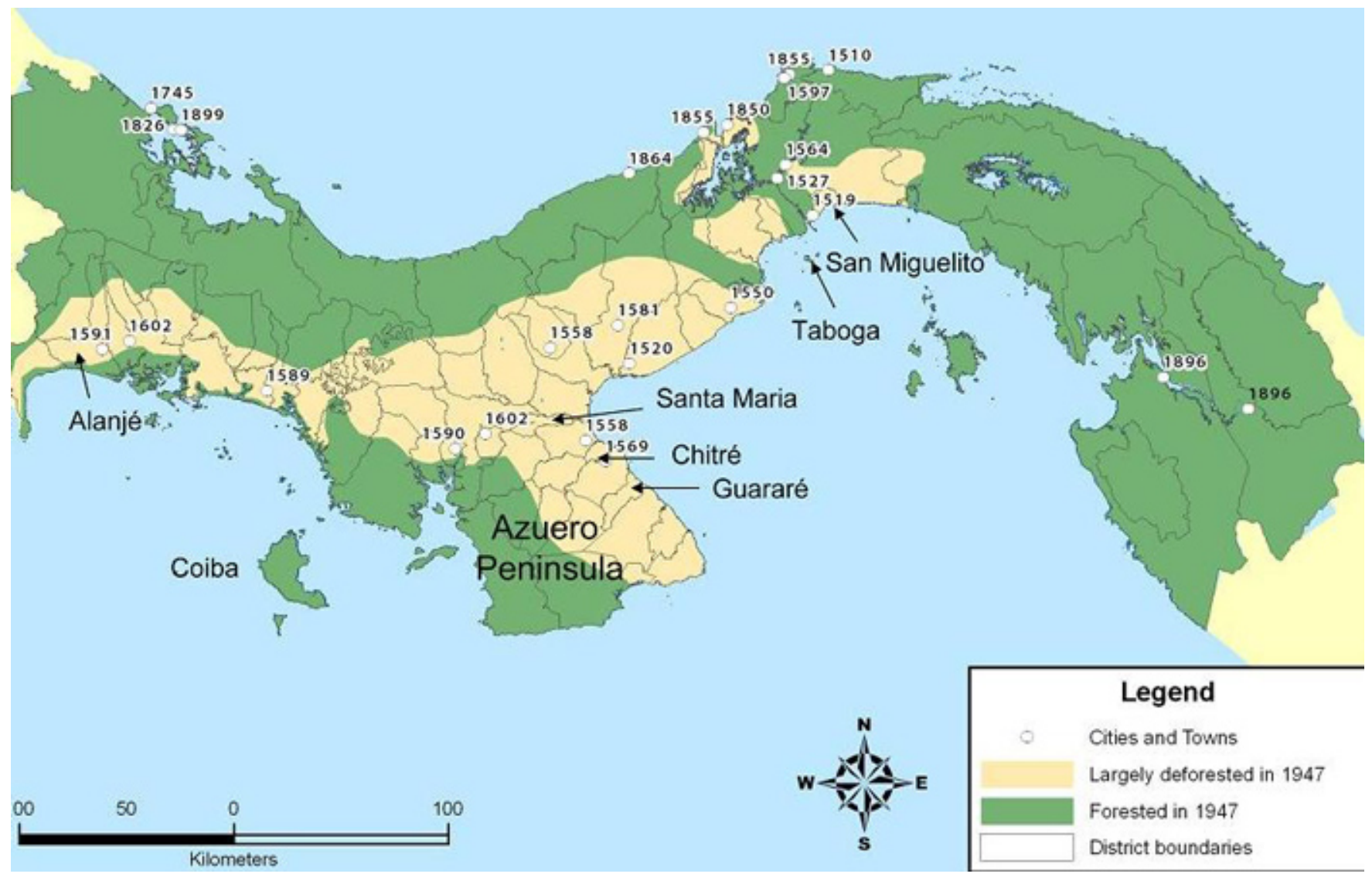

uncinariasis (parasitic worms) were endemic when the first government-assigned physicians arrived in the Azuero Peninsula. President Belisario Porras Barahona of the newly formed Republic of Panama sent those first physicians and built the first schools and roads accessible year round throughout the Pacific coastal plain between 1912 and 1924.

Government measures reduced mortality and increased population growth, which averaged $2.1 \%$ $\mathrm{yr}^{-1}$ between 1911 and 1940 when there were $6.23 \times$ $10^{5}$ Panamanians. The privatization of communal lands allowed agricultural intensification on the Pacific coastal plain, and new jobs created by the Panama Canal, United States military bases, and economic growth in Panama City absorbed most of the population increase until the end of World War II. At this time, the United States reduced the number of troops in Panama from $1.0 \times 10^{5}$ to $1.0 \times$ $10^{4}$, the wartime economy plunged into recession, and population growth surged to $3.0 \% \mathrm{yr}^{-1}$ between 1950 and 1970 . The stage was set for migration to the agricultural frontier.

The first land-use survey of Panama was completed in 1947 and is the basis of our historical perspective (Garver 1947). Heckadon Moreno (1984) converted Garver's (1947) verbal descriptions into a landcover map (Fig. 1). In 1947, the dry Pacific coastal plain was largely in agriculture and the rest of 
Panama was largely forested. The Pacific coastal plain rises into hilly and mountainous country to the north and in the southern and western Azuero Peninsula, where high rainfall and topographic relief limited settlement. Panamanians today refer to the area that was deforested in 1947 as the dry Pacific arc, and we use this term here.

\section{METHODS}

Panamanian Government agencies provided the three open-access data sets. The Contraloría provided the decennial population censuses of 1990 and 2000 (http://www.contraloria.gob.pa/dec/redatam/ index censospma.htm) and the national agricultural census of 2000 (http://www.contraloria.gob.pa/dec/ aplicaciones/agropecuario final/censo.htm). The Autoridad Nacional de Ambiente (ANAM) provided land cover for 1992 and 2000 (Fig. 2), detailed definitions of 16 land-cover types, and descriptions of the protocols used for LandSat image analysis and extensive post-analysis verification and correction (http://www.anam.gob.pa/ Sif\%202002/metodologia.htm). The post-analysis verification and correction included site visits wherever the land-cover classification was problematic and the acquisition of georeferenced photographs that were used to refine the problematic land-cover classification. Aerial photographs of two large districts $\left(7007 \mathrm{~km}^{2}\right)$ and the critical Panama Canal watershed $\left(2892 \mathrm{~km}^{2}\right)$ were used to further verify and refine the land-cover classification. Quantitative estimates of the accuracy of the classification were not made; rather, all available information was used to correct the final classification. The extensive photographic refinements suggest that few errors remain.

Our analyses were at the spatial scale of districts. Panama is divided into nine provinces and four indigenous areas (comarcas), which are subdivided into 76 districts (Fig. 1). We excluded the two smallest districts. The median area of the remaining 74 districts was $599 \mathrm{~km}^{2}$ (range: $85-7001 \mathrm{~km}^{2}$ ). This spatial scale is appropriate to minimize withindistrict variation in rainfall and soil fertility (Instituto de Investigación Agropecuaria de Panamá 2006).

Several districts were created after 1990. This creates problems because the ANAM provides land cover for present-day districts, whereas the Contraloría provides data for districts at the time of each census. Seven districts that compose the Ngobe Comarca were created in 1998 from nine older districts, and Mariato was separated from Montijo in 2001. Population census data for the next smaller political unit or corregimiento were used to align past and present boundaries for eight districts (Appendix 1). This was impossible for 10 districts for which the boundaries in 2000 divided corregimientos from 1990. These 10 districts lack data for the 1990 population census. We therefore used values from 2000 to include these 10 districts in analyses of current land use. Mariato and Montijo presented an additional problem because they were separated after the 2000 agricultural census and agricultural census data are unavailable for corregimientos. The agricultural census is also incomplete for the 10 districts that compose the indigenous comarcas. For these reasons, we had to exclude Montijo, Mariato, and the 10 districts within the comarcas from analyses involving agricultural variables.

We calculated the proportion of the surface area of each district that supported agriculture, secondary forest $<5 \mathrm{yr}$ old (rastrojo), older secondary forest, and mature forest after removing areas inappropriate for both agriculture and forest. The areas removed included open water $\left(920 \mathrm{~km}^{2}\right.$ total in 2000), tidal flats (21 km² of albinas), and low vegetation inundated by fresh water $\left(337 \mathrm{~km}^{2}\right)$. For agriculture, we pooled row crops, pasture, subsistence agriculture, and tree plantations. Tree plantations were not distinguished in 1992 and covered just $235 \mathrm{~km}^{2}$ in 2000 . For older secondary forest, we pooled mature secondary forest and secondary and altered natural forests. Mature secondary forest $\left(706 \mathrm{~km}^{2}\right)$ is limited to the Panama Canal area, where it can be distinguished because the land-use history is known. Satellite spectral signals of secondary and primary forest merge after approximately $15 \mathrm{yr}$ of secondary succession in Amazonia (Nelson et al. 2000), and the same is probably true in Panama. Thus, we also pooled mature secondary forest with mature forest. Our results were robust to this minor change; thus, we only present results with mature secondary forest pooled with secondary forest. For total secondary forest, we pooled rastrojo and older secondary forest. For mature forest, we pooled mature forest, mangroves, mixed inundated forest, orey (Campnosperma panamensis) forest, and homogeneous and mixed cativo (Prioria copaifera) forests. The final four categories refer to forests flooded by fresh water. Orey forms natural monocultures on the 
Fig. 2. Land-cover maps for 1992 and 2000 for the Republic of Panama. Land cover was determined from LandSat image analyses conducted by the Autoridad Nacional de Ambiente of the Republic of Panama (http://www.anam.gob.pa/Sif\%202002/metodologia.htm).

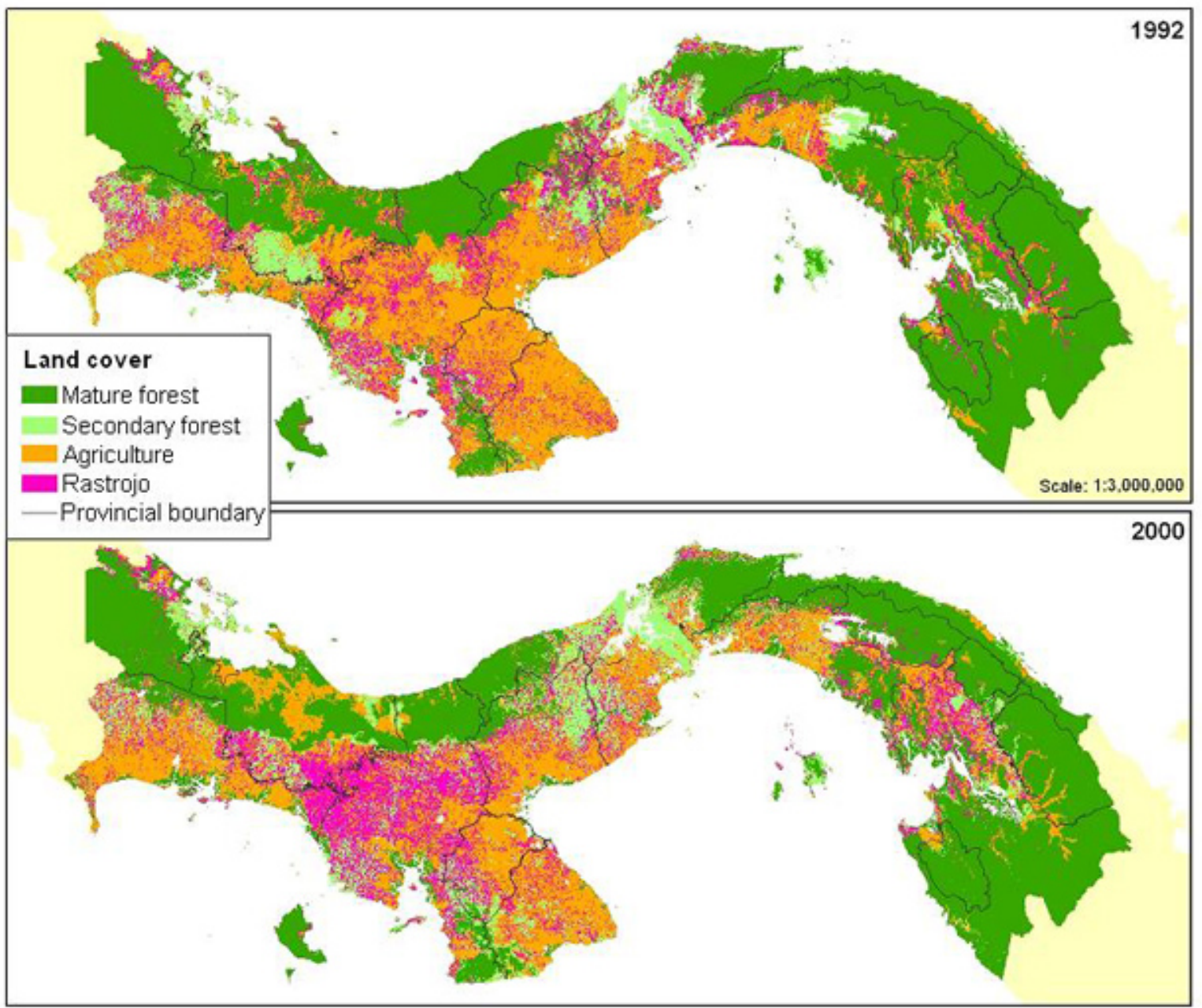

Caribbean coast; cativo forms natural monocultures on both coasts. For total forest cover, we pooled total secondary forest and mature forest. We calculated the 1992-2000 change in total forest cover and total secondary forest cover as the ratio of the value in 2000 to that in 1992 .

We used the population censuses to define three variables: population density, the density of agricultural workers, and a human poverty index (HPI). Population density was calculated as population divided by area. The density of agricultural workers was calculated as the number of agricultural workers, fishermen, and hunters divided by area. The national census pools agricultural workers, fishermen, and hunters because virtually all hunters and most fishermen (with exceptions in urban centers) also practice subsistence agriculture. The HPI incorporated housing quality, population age structure, literacy, family income, and profession in a principal components analysis (Appendix 2). The proportion 
of improvised housing was calculated as the number of improvised plus semi-permanent living places divided by the total number of living places. The proportion of children was calculated as the number of children < $15 \mathrm{yr}$ old divided by the total population. The proportion of illiterate was calculated as the number of illiterate divided by the total population $\geq 10 \mathrm{yr}$ old. The proportion of very poor families was calculated as the number of families with monthly income < US $\$ 100$ divided by the total number of families. US\$100 is the smallest income reported. The proportion of agricultural workers was calculated as the number of agricultural workers, fishermen, and hunters divided by the total number of workers. A logarithmic transformation of the proportion of improvised housing and angular or arcsine squareroot transformations of the other variables achieved normality and linearized the 10 pairwise relationships (Appendix 2). All 10 pairwise relationships were strong $\left(r^{2}>0.50\right)$. The first principal component explained $86 \%$ of the overall variation for 74 districts (the two smallest districts were excluded). Large factor scores were associated with illiteracy (0.94), monthly income < US\$100 (0.95), improvised housing (0.93), agricultural workers (0.94), and children (0.88). Thus, districts with a large HPI have high levels of illiteracy, poverty, improvised housing, children, and agricultural workers.

The agricultural census provided the data necessary to estimate gross income for each crop and type of animal. This included the price that the farmer received for each crop and each type of animal for each province, the area in pasture and planted in each crop for each district, and the number of animals sold and the amount of each crop harvested for each district. We used these data to define three variables: gross income per hectare from crops, from cattle, and from all agriculture. The gross income per hectare from crops was calculated as the product of the price and amount of harvest summed over all crops and divided by the total area in crops. The gross income per hectare from cattle was calculated as the product of the price and number of cattle sold divided by the total area in pasture. The gross income per hectare from all agriculture was calculated as the gross income from crops, cattle, and other animals divided by the total area devoted to agriculture. The agricultural census also provided the proportion of farms that lacked titles, which was calculated as the number of farms for which the owners lacked any title to the land divided by the total number of farms.
We used the Heckadon Moreno-Garver map (Fig. 1) to define a final dichotomous variable: deforested versus forested in 1947. A district was forested in 1947 if $\geq 50 \%$ of its area was forested. Thus, 36 and 38 districts were deforested and forested, respectively, in 1947.

\section{Analyses}

We used the Kolmogorov-Smirnov test to evaluate the null hypothesis that change between 1990 (1992 for land cover) and 2000 was indistinguishable for districts that were deforested before or after 1947. We quantified change as the ratio of 2000:1990 values (or 2000:1992 values for land-cover types) for total population, total agricultural land cover, total forest cover, and agricultural workers expressed as an absolute number and as a proportion of the total population. We used a nonparametric test because ratios tend to violate parametric assumptions.

We performed a multiple regression analysis using total forest cover in 2000 as the dependent variable and six independent variables: HPI, 1947 forest cover, density of agricultural workers, gross income per hectare from all agriculture, total population density, and proportion of farms that lacked land titles. Logarithmic and angular transformations, respectively, were used to normalize the final two variables and to linearize their relationships with total forest cover. We used effects coding for the dichotomous variable of 1947 forest cover. Agricultural income and land title data were not available for Montijo, Mariato, and 10 districts in the indigenous comarcas, leaving $N=62$ districts. We therefore repeated this first multiple regression analysis without the two independent variables that were derived from the agricultural census to include these 12 districts ( $N=74$ districts).

We performed two additional multiple regression analyses using the change in total forest cover and secondary forest cover between 1992 and 2000, respectively, as dependent variables and the same six independent variables. We excluded three districts, i.e., Chitré, Guararé, and Santa María, from these analyses because their 1992 forest cover was $<20 \mathrm{~km}^{2}$ and relatively modest increases in absolute forest cover caused the 2000:1992 forest cover ratios (dependent variable) to become large outliers.

We built multiple regression models interactively to minimize collinearity among the independent 
variables included in the final model. Collinearity occurs when condition indices, defined as the square-root of the largest eigenvalue divided by each smaller eigenvalue, are > 15 (SYSTAT 2004). The initial regression models included all independent variables. Independent variables with the least significant regression coefficients (largest $P$-values) were then successively removed. Collinearity was evaluated when all remaining regression coefficients were significant. If collinearity was present, we compared multiple regression models for all possible combinations of the collinear independent variables and selected the final model to minimize collinearity (all condition indices < 15) and maintain the adjusted squared multiple $R$. All analyses were performed using SYSTAT@ 11.0 (SYSTAT 2004). Appendix 3 contains all of the data used in these analyses.

\section{RESULTS}

\section{Variation among districts within Panama}

Among-district variation was surprisingly large. Total forest cover averaged $61 \%$ and ranged from $12 \%$ to $98 \%$. Total agricultural cover averaged $38 \%$ and ranged from $1.3 \%$ to $87 \%$. Population density (individuals $/ \mathrm{km}^{2}$ ) averaged 53 and ranged from 1.5 to 870 . The population density of agricultural workers (individuals $/ \mathrm{km}^{2}$ ) averaged 12 and ranged from 1.3 to 50 . Additional ranges were $2.2-90 \%$ for improvised housing, $6.9-87 \%$ for monthly family income < US $\$ 100,21-52 \%$ for children < $15 \mathrm{yr}$ old, $1-57 \%$ for illiteracy, and $1.7-93 \%$ for agricultural workers as a percentage of all workers. Thus, Panama contains vast regional differences.

Forest and agriculture covered the entire surface area of most districts (Fig. 3). San Miguelito is the second smallest district $\left(50 \mathrm{~km}^{2}\right)$ and is a largely urban exception. San Miguelito and the smallest district, i.e., the resort island of Taboga $\left(11 \mathrm{~km}^{2}\right)$, were excluded from all analyses. The relative importance of forest and agriculture in 2000 differed significantly with historical land use, with forest being more important in districts that were largely forested in 1947 ( $t$-test, $t=-8.84, P<0.001$; Fig. 3).

\section{Population and land-cover changes relative to 1947 land cover}

Population growth between 1990 and 2000 did not differ significantly between districts that were deforested before and after 1947 (KolmogorovSmirnov $[\mathrm{KS}]$ test, $P=0.94)$. Agricultural workers expressed as a proportion of all workers decreased in virtually all districts (Fig. 4A). This decrease was significantly greater in districts that were deforested before 1947 (mean 1990:2000 ratio \pm SD $=0.68$ \pm 0.11 ) than in districts that were deforested after 1947 (0.81 \pm 0.15 ; KS test, $P<0.001)$. The density of agricultural workers decreased in districts that were deforested before $1947(0.78 \pm 0.076)$ and tended to remain relatively constant in districts that were deforested after $1947(0.91 \pm 0.21$; KS test, $P$ $=0.001$; Fig. 4B). Nonetheless, the 2000 density of agricultural workers was significantly greater in districts that were deforested before 1947 than in districts that were deforested after 1947 (KS test, $P$ $=0.005$; Fig. 4B).

Total agricultural land cover tended to decrease in districts that were deforested before 1947 (mean $1992: 2000$ ratio $\pm \mathrm{SD}=0.81 \pm 0.22$ ) and tended to increase in districts that were deforested after 1947 $(1.18 \pm 0.52$; KS test, $P<0.001$; Fig. 5A). Total forest cover tended to increase in districts that were deforested before $1947(1.76 \pm 1.06)$ and tended to remain unchanged in districts that were deforested after 1947 (1.04 \pm 0.22 ; KS test, $P<0.001$; Fig. 5B).

\section{Pasture versus crops}

Pasture covered $79 \%$ of the active agricultural land in Panama in 2000 and ranged from a minimum of $23 \%$ to $94 \%$ of active agricultural land across districts (Fig. 6A). Returns on cattle might therefore be expected to exceed returns on crops. However, the opposite was true (Fig. 6B). The median gross income per hectare from cattle and from crops were US\$66 and US\$383 per hectare, respectively. The percentage of active agricultural land in pasture explained $24 \%$ of the among-district variation in gross agricultural income per hectare (data not shown, $P<0.001$ ). 
Fig. 3. The relationship between agricultural land cover and forest cover in 2000 for the 76 districts that compose Panama. Brown downward-pointing triangles indicate districts that were largely deforested before 1947; green upward-pointing triangles indicate districts that were largely forested in 1947. The inset is a histogram of the areas of districts. Districts that fall on the negatively sloping diagonal line are covered entirely by forest and agriculture. Agricultural land cover includes market-oriented crops and animals, subsistence agriculture, and tree plantations. Forest cover includes all natural vegetation that potentially has a closed tree canopy, including very young secondary forest or rastrojo ( $<5 \mathrm{yr}$ old), older secondary and mature terra firme forests, mangrove forests, and other flooded forests dominated largely by cativo (Prioria copaifera) or orey (Campnosperma panamensis). The district of San Miguelito is largely urban and was omitted from all analyses. Open water, tidal flats and low inundated vegetation were excluded.

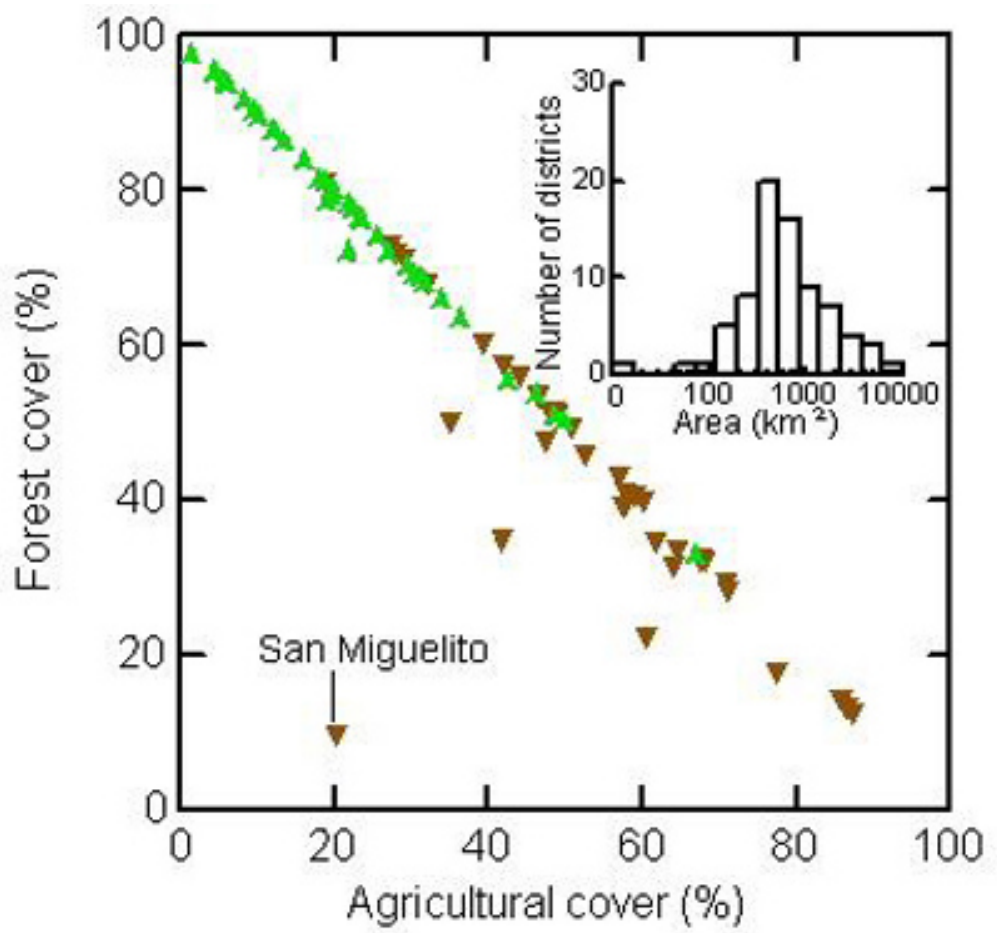

\section{0 forest cover: regression analyses}

Two different multiple regression models explained $>60 \%$ of the among-district variation in total forest cover in 2000 . When the agricultural census data were included ( $N=62$ districts), gross income per hectare from all agriculture was removed because its regression coefficient was statistically indistinguishable from zero $(P=0.216)$. The adjusted squared multiple $R$ was 0.693 for the model with five independent variables; however, collinearity was present (maximum condition index $=19.4$ ) because of relatively strong positive correlations between total population density and the human poverty index (HPI; $\left.r^{2}=0.55\right)$ and between total population density and the density of agricultural workers $\left(r^{2}=0.40\right)$. When any one of these three collinear independent variables was removed from the model, the two collinear variables that remained had insignificant regression coefficients. All three collinear variables were therefore removed. The two remaining independent variables, i.e., 1947 forest cover and the proportion of farms that lacked titles, explained $67.3 \%$ of the among-district variation in total 2000 forest cover $\left(F_{2,59}=60.7, P<0.001\right.$; Fig. 7). The adjusted 
Fig. 4. The relationship between populations engaged in agriculture in 1990 and 2000 (A) as a percentage of the total population and (B) as absolute density for districts of Panama. The dashed line indicates a 1:1 relation. Agricultural workers declined as a percentage of the population in 70 of 74 districts. The absolute density of agricultural workers declined in all districts that were largely deforested before 1947 (brown downward-pointing triangles) and tended to remain unchanged in districts that were first deforested after 1947 (green upward-pointing triangles).
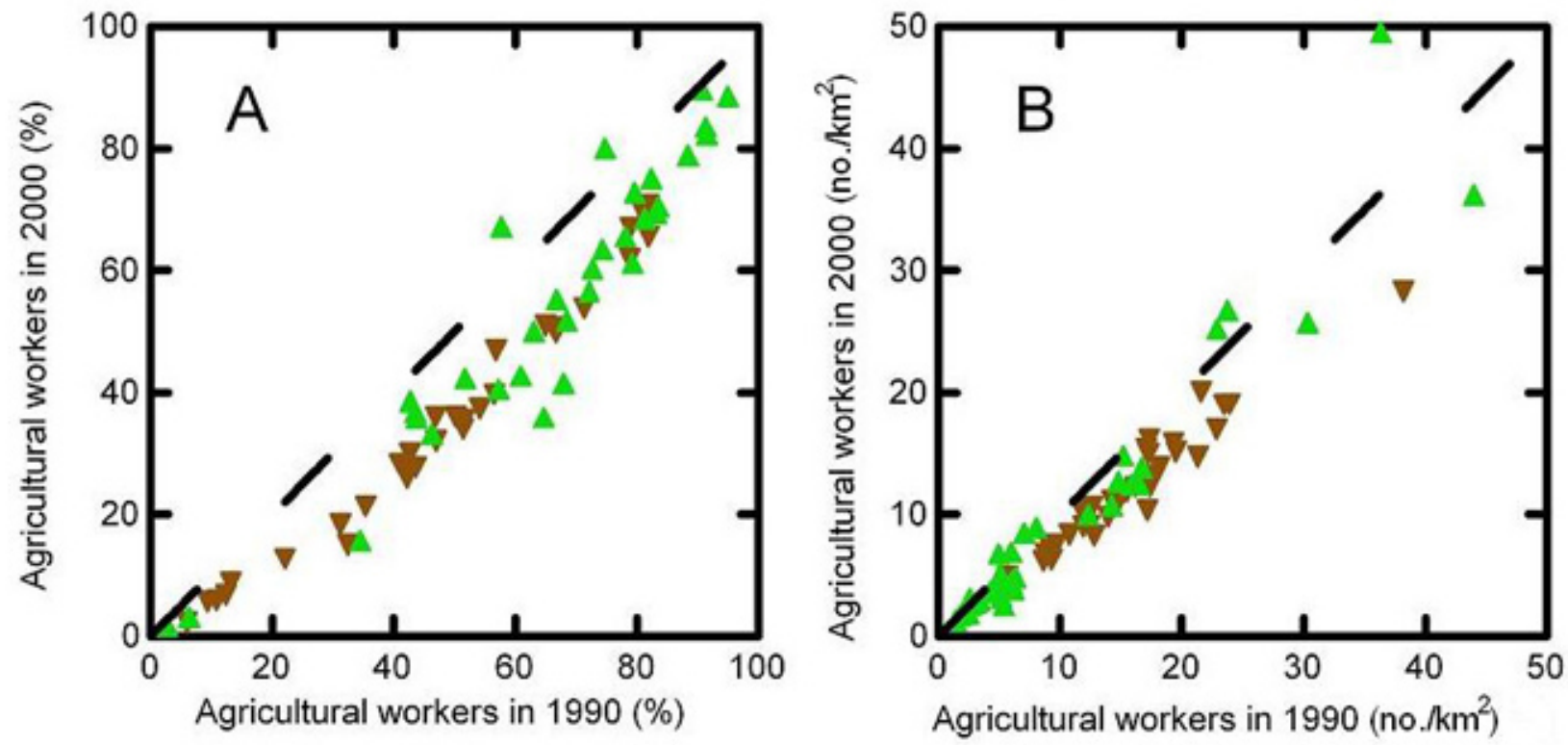

squared multiple $R$ for this model was 0.662 , which is nearly indistinguishable from that of 0.693 for the model that contained the three additional collinear independent variables.

We repeated this multiple regression analysis without the independent variables that were derived from the national agricultural census so that we could include Mariato, Montijo, and the 10 districts that compose the indigenous comarcas $(N=74$ districts). Districts within the comarcas are characterized by poverty (large HPI scores) and a wide range of population densities, which reduced the collinearity. Total population density was removed from the multiple regression model because its regression coefficient was indistinguishable from zero $(P=0.249)$. The three remaining variables explained $61.2 \%$ of the among-district variation in 2000 forest cover, and collinearity was absent (maximum condition index $=6.25 ; F_{3,70}=36.7, P$ $<0.001$; Fig. 8).
To summarize, two quite different multiple regression models explained $>60 \%$ of the amongdistrict variation in 2000 forest cover depending upon whether agricultural data and the 12 districts that lacked these data were included (Figs. 7 and 8). In both models, districts that were largely forested in 1947 had significantly greater 2000 forest cover than did districts that were largely deforested in 1947. When the agricultural census data were included, 2000 forest cover increased with the proportion of farms that lacked land titles (coefficient $=0.47, t=5.94, P<0.0001$; Fig. 7). When the agricultural census data were excluded and the 12 additional districts were included, 2000 forest cover decreased with the population density of agricultural workers (coefficient $=-0.69, t=$ $-2.84, P=0.0059$; Fig. 8B) and increased with the HPI (coefficient $=0.069, t=3.25, P=0.0018$; Fig. $8 \mathrm{~A})$. The HPI is greater when the human condition is more difficult, so the 2000 forest cover increased with increasing poverty (Fig. 8A). 
Fig. 5. The relationship between the 1992 and 2000 land cover in (A) agriculture and (B) forest in districts of Panama. The dashed line indicates a 1:1 relation. The amount of agricultural area tended to decrease and that of forested area tended to increase in districts that were largely deforested before 1947 (brown downward-pointing triangles). The amounts of agricultural and forested area tended to be relatively constant in districts that were deforested after 1947 (green upward-pointing triangles).
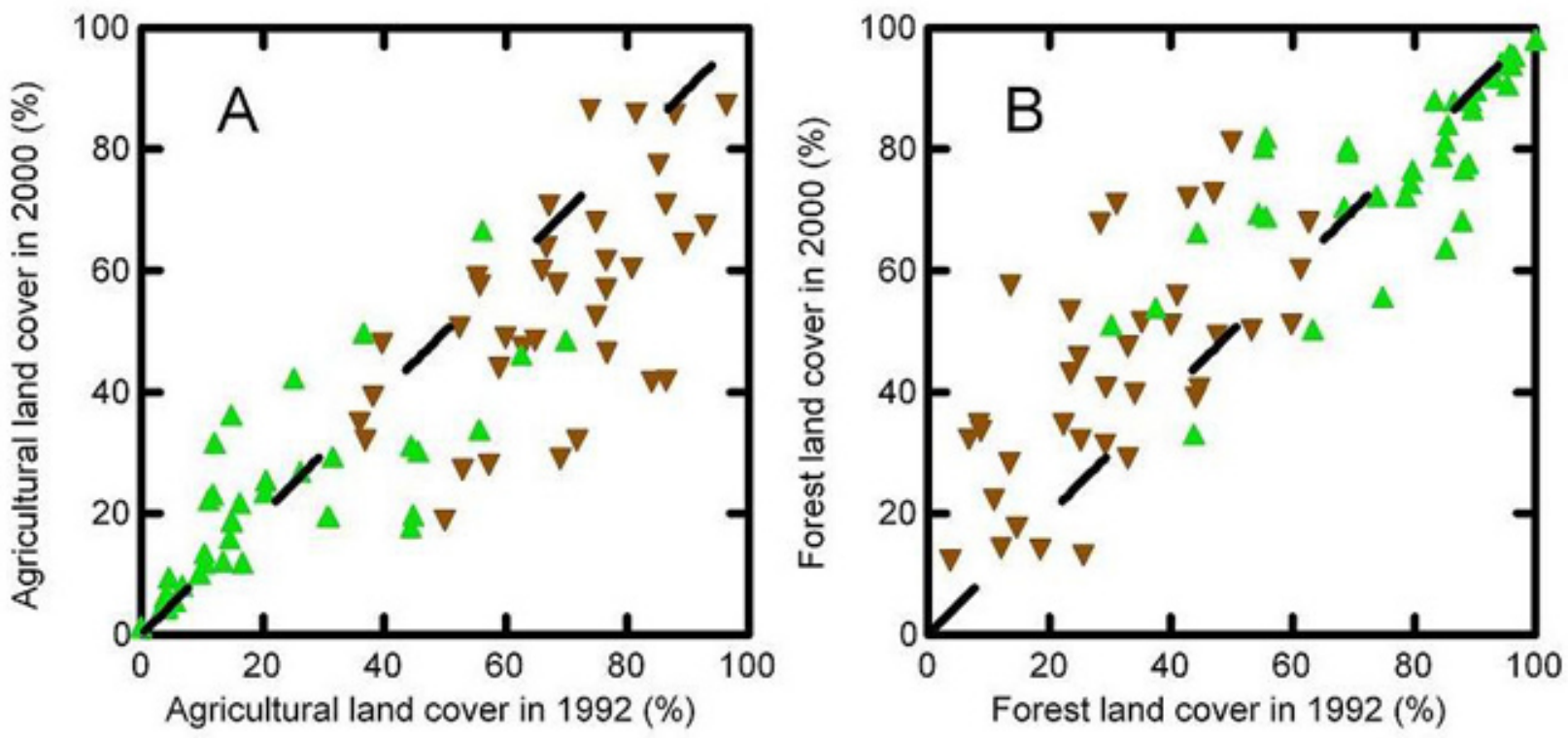

\section{2 to 2000 forest-cover change: regression analyses}

Multiple regression analyses for 1992-2000 forestcover change were robust with respect to the inclusion of the 12 districts that lacked agricultural data. Four independent variables had nonsignificant regression coefficients for both total and secondary forest cover when the agricultural census data were included ( $N=59$ districts). Only 1947 forest cover and the logarithm of gross income per hectare from all agricultural activity remained. These two independent variables explained 23.5 and $20.7 \%$ of the among-district variation in 1992-2000 change for total and secondary forest cover, respectively $\left(F_{2,56}=8.59, P<0.001\right.$ for total forest cover; $F_{2,56}=$ $7.30, P=0.002$ for secondary forest; Fig. 9 and data not shown, respectively). The largest condition indices were 14.1 and 14.3 for total and secondary forest cover, respectively.

A similar result was obtained when the agricultural census data were excluded ( $N=71$ districts). The same independent variables had nonsignificant regression coefficients and were removed from analyses for both total and secondary forest cover. The one remaining independent variable, 1947 forest cover, explained 18.2 and $7.2 \%$ of the amongdistrict variation in 1992-2000 change for total and secondary forest cover, respectively $\left(F_{1.69}=15.3, P\right.$ $<0.001$ for total forest cover; $F_{1,68}=5.26, P=0.025$ for secondary forest cover; data not shown). The district of Alanjé, where the amount of land area dedicated to industrial rice production grew substantially in the 1990s, was an outlier and was excluded for secondary forest cover only. Collinearity is not an issue when these is only a single independent variable.

To summarize, 1992-2000 forest-cover change was consistently positive in districts that were largely deforested in 1947 and was significantly greater in these districts than in those that were still largely forested in 1947 (Figs. 5B and 9). The 1992-2000 forest-cover change was also negatively related to gross agricultural income per hectare $($ coefficient $=$ 
Fig. 6. The number of districts of Panama characterized by (A) land area in crops and pasture and (B) gross income per hectare from crops and pasture. On average, land cover was 3.8 times greater for pasture than for crops, whereas gross income was 6.7 times greater for crops than for pasture.

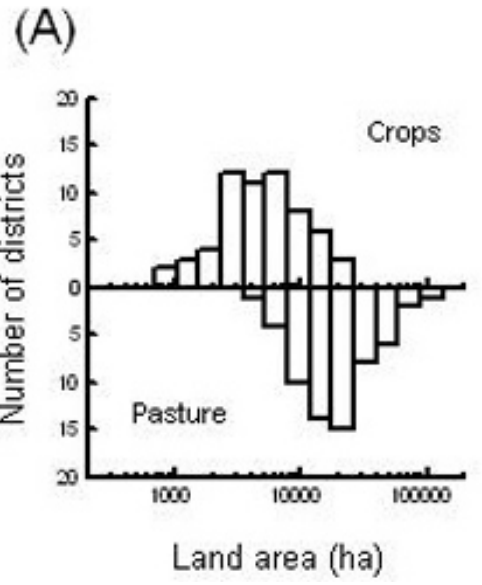

(B)

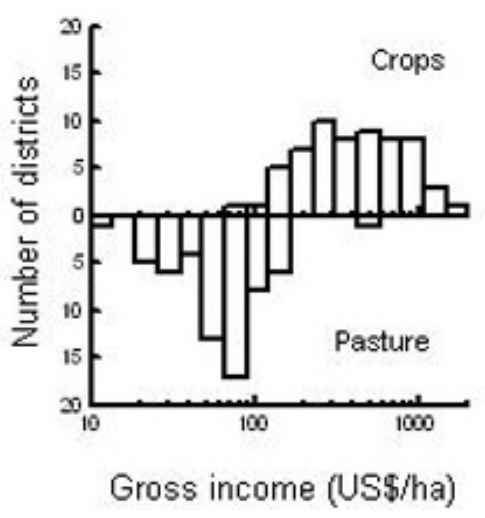

$-0.15, t=-2.48, P=0.018$; Fig. 9). The proportion of farms that lacked land titles was also negatively related to gross agricultural income per hectare $\left(r^{2}\right.$ $=0.26, P<0.001$; Fig. 10).

\section{DISCUSSION}

After $45 \mathrm{yr}$ of net forest loss, Panama experienced a $0.36 \%$ annual increase in total forest cover between 1992 and 2000 (Figs. 1 and 2, Table 1). This increase in forest cover occurred as the proportion of workers employed in agriculture, fishing, and hunting declined throughout the country (Fig. 4A). The absolute number of agricultural workers also declined in districts that were settled in the 16th century and were largely deforested before 1947 (Figs. 1 and 4B). An index of human poverty, 1947 land cover, and the population density of agricultural workers explained $61 \%$ of the variation in forest cover observed among districts in 2000 (henceforth 2000 forest cover; Fig. 8). Modern Panamanian forests are concentrated in areas where people are poor and few in number and where colonial-era agriculture was absent (Figs. 1, 3, and 8). Historical land use and current gross income per hectare of agricultural land also explained $23.5 \%$ of the among-district variation in forest cover change observed between
1992 and 2000 (Fig. 9). Dismal gross incomes from agriculture appear to reinforce the trend for Panamanian forests to be concentrated in areas where people are poor.

The role of land titles should be consistent with this synthesis. Historical land use and the proportion of farms that lacked land titles explained $67 \%$ of the among-district variation in 2000 forest cover (Fig. 7 ). When the variable for land titles was included in the multiple regression models, however, the index of human poverty and the population density of agricultural workers no longer explained a significant portion of among-district variation in 2000 forest cover. The proportion of farms that lacked land titles is inversely related to gross agricultural income per hectare (Fig. 10). This link between land titles and agricultural income suggests that land titles might be a proxy for the human poverty index and population. Time and several small fees are required to obtain land titles in Panama. Hence, in recently deforested districts, land titles might be a proxy for recent agricultural returns, as well as time since colonization. Land titles lapse when land values decrease and families emigrate. Hence, in historically deforested districts, land titles might be a proxy for long-term agricultural returns. If limited agricultural returns impoverished people prior to emigration, then the circle would be complete and the proportion of 
Fig. 7. The relationship between total forest cover in 2000 and the proportion of farms that lacked any form of title for 62 districts in Panama. The lack of land titles and history of deforestation explained $67.3 \%$ of the among-district variation in forest cover in 2000. Brown downward-pointing triangles indicate districts that were largely deforested before 1947; green upward-pointing triangles indicate districts that were largely forested in 1947.

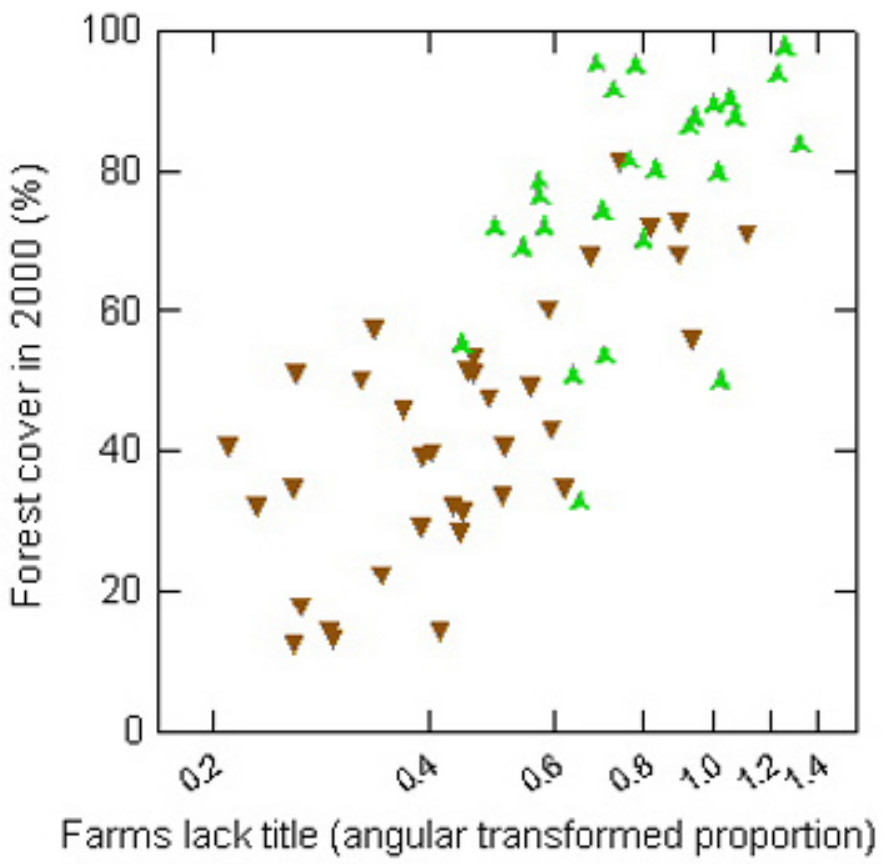

farms that lacked land titles might indeed act as a proxy for human poverty and population density. A more detailed analysis of household economies will be necessary to evaluate this hypothesis.

\section{Additional characteristics of forest transitions in Panama}

The national-level forest transition that we have described integrates two very different regions that lie on different points along the temporal sequence leading to forest transition. The dry Pacific arc was largely deforested in the Spanish colonial era and remained largely deforested in 1947 (Fig. 1; Jaén Suárez 1981). Forest covered $34 \%$ of the dry Pacific arc in 1992, and a strong forest transition followed, with total forest cover increasing by $4.1 \%$ annually over the next 8 yr (Fig. 2). In contrast, the remainder of Panama was largely forested in 1947 and remained so in 1992, when forest still covered $83 \%$ of the land (Figs. 1 and 2). These 1947 frontier areas experienced a small decline in total forest cover of $0.2 \%$ annually between 1992 and 2000 (Figs. 2 and $5 \mathrm{~B})$. We next consider two attributes of these two regions with respect to current ideas concerning forest transitions.

Rudel et al. (2005) distinguished two types of forest transition: those caused when a scarcity of forest products prompts governments and landowners to convert crops or pasture to tree plantations; and those caused when economic growth creates jobs that draw farmers off the land, allowing natural secondary forest succession in abandoned fields. Both have occurred in Panama. Tree plantations were virtually absent in 1992 (Stuart J. Wright personal observation). Tax incentives stimulated 
Fig. 8. The relationship between total forest cover in 2000 and (A) an index of human poverty and (B) the population density of agricultural workers for 74 districts in Panama. The human poverty index (HPI) is ordered from wealthiest to poorest, with the seven districts in the Ngobe indigenous area being among the poorest. The HPI integrates literacy, poverty (monthly family income < US\$100), age structure (proportion < $15 \mathrm{yr}$ old), housing (proportion improvised), and occupation (proportion in agriculture) as first principal component factor scores. Brown downward-pointing triangles indicate districts that were largely deforested before 1947; green upward-pointing triangles indicate districts that were largely forested in 1947.
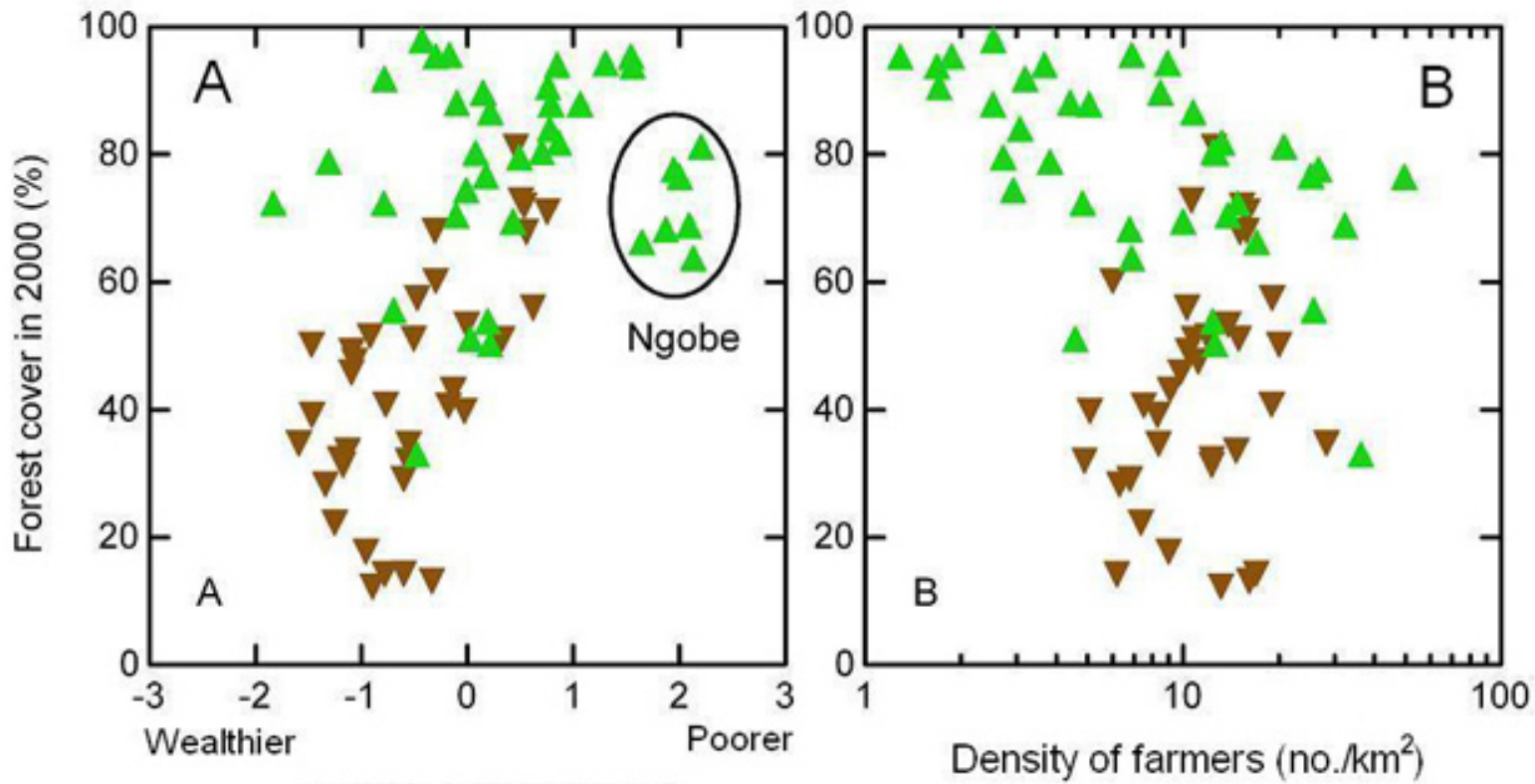

Human poverty index

the establishment of $235 \mathrm{~km}^{2}$ of tree plantations by 2000 (Gutiérrez 2005). These tree plantations compose $11 \%$ of the contemporaneous reduction in agricultural land cover; we included tree plantations as agriculture in Table 1 , so the new tree plantations must be added to the reduction in agricultural land cover reported in Table 1 to arrive at $11 \%$. Thus, government policy stimulated by a scarcity of forest products contributed $11 \%$ of the forest transition observed between 1992 and 2000 in Panama. The remainder was a result of natural secondary forest succession on abandoned agricultural land.

Perz and Skole (2003) drew attention to the difference between mature and secondary forests during forest transition. They speculated that mature forest area would follow an S-shaped trajectory with a slow initial decline, a rapid decline as total forest cover decreases, and an ongoing slow decline even after the forest transition and increases in total forest cover. Unfortunately, this trajectory describes the situation in Panama well. The historically deforested dry Pacific arc and historically forested 1947 frontier areas lost $151 \mathrm{~km}^{2}$ and $3379 \mathrm{~km}^{2}$ of mature forest between 1992 and 2000, respectively; these losses are very similar when expressed as a percentage of mature forest area in 1992, at 11 and $10 \%$, respectively. This interpretation is limited, however, by the inability of LandSat image analyses to discriminate mature forests from secondary forests after as little as $15 \mathrm{yr}$ of secondary succession (Nelson et al. 2000). Additional data are needed to evaluate mature and secondary forest dynamics.

The data reported here for total, national-level forest cover (Table 1) differ from those reported by the 
Fig. 9. The relationship between the change in total forest cover and gross agricultural income per hectare in 2000 for 57 districts in Panama. The change in total forest cover is expressed as the ratio of forest area in 2000 to that in 1992. Brown downward-pointing triangles indicate districts that were largely deforested before 1947; green upward-pointing triangles indicate districts that were largely forested in 1947.

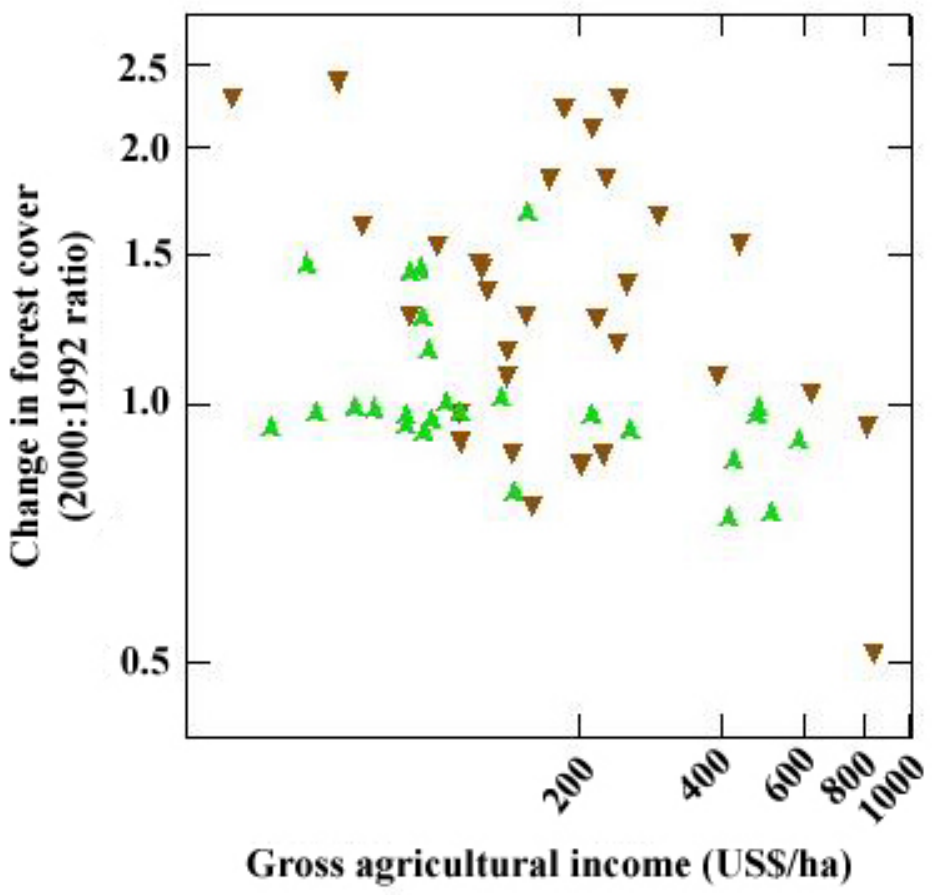

United Nations Food and Agriculture Organization in the 2005 assessment of forest resources (Food and Agriculture Organization 2006) for three reasons. First, the Food and Agriculture Organization (2006) extrapolated the 1992 and 2000 data used here to estimate values for 2005 (Gutiérrez 2005). Second, the Food and Agriculture Organization (2006) included $235 \mathrm{~km}^{2}$ of tree plantations as forest. Most importantly, the Food and Agriculture Organization (2006) excluded rastrojo from measures of forest (Gutiérrez 2005) and therefore reported less forest area than reported here (Table 1). Rastrojo refers to secondary forest that is < 5 yr old. The Food and Agriculture Organization's (2006) definition of forest includes "areas under reforestation that have not yet reached but are expected to reach a canopy cover of 10 percent and a tree height of $5 \mathrm{~m} \mathrm{(...)} \mathrm{[and]} \mathrm{(...)}$ temporarily unstocked areas, resulting from human intervention or natural causes, which are expected to regenerate." Secondary forests $<5$ yr old clearly meet this definition, and our treatment of rastrojo accords with the Food and Agriculture Organization's (2006) definition.

\section{The role of cattle}

The first Spaniards colonized the dry Pacific arc of Panama because the rainfall regime was most suitable for their cattle (Fig. 1; Jaén Suárez 1981). The focus of Panamanian agriculture on cattle has declined since the colonial era; the number of cattle per person declined from 4.4 in 1607 to 2.3 and 0.54 in 1790 and 2000, respectively (the 1607 number includes horses; Jaén Suárez 1981). Nonetheless, pasture continued to occupy 3.8 times more land than did crops in 2000 , even though crops generated 6.7 times greater gross incomes per hectare (Fig. 6). 
Fig. 10. The relationship between the proportion of farms that lack land titles and gross income from all agricultural activity for 62 districts in Panama. Brown downward-pointing triangles indicate districts that were largely deforested before 1947; green upward-pointing triangles indicate districts that were largely forested in 1947.

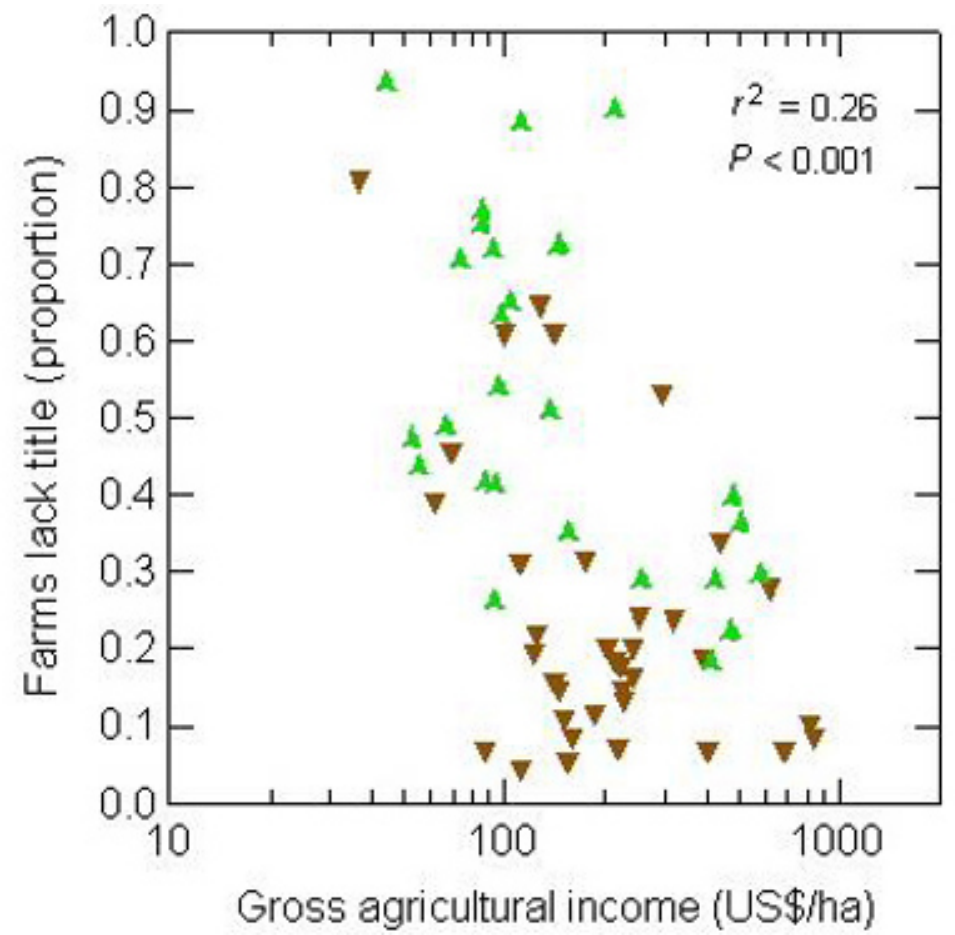

We can only speculate about the causes of this paradox. We think that limitations on crops imposed by soil fertility and climate are not decisive factors for two reasons. First, pasture and crops are routinely found side by side. Second, at a slightly larger spatial scale, pasture accounts for a minimum of $23 \%$ of all active agricultural land within a district. Thus, cattle are ubiquitous, even though variation in soil fertility and climate is much greater among districts than within districts (Instituto de Investigación Agropecuaria de Panamá 2006).

Heckadon Moreno (1984) presents a powerful analysis of the cattle economy of Panama. Cattle have two principal advantages for poor land owners. First, crops are vulnerable to pests and drought, whereas cattle are less risky. Second, cattle can be held indefinitely and sold when cash is required. Personnel at the Instituto de Investigación Agropecuaria de Panamá also think that undercapitalization prevents many land owners from switching from cattle to more profitable crops (Benjamin Name personal communication). In sum, cattle provide financial security for land owners of limited means (Heckadon Moreno 1984).

Regardless of its cause, the preponderance of lowincome pasture over higher income crops is likely to contribute to the limited forest transition now underway in Panama. Poor people are found in areas near forest in Panama for two reasons. First, the poor and landless migrate to remote agricultural frontiers. Second, and more importantly, low farm incomes impoverish farmers. Land titles are less likely to be maintained or obtained in these areas (Fig. 10), and agricultural land is eventually abandoned to secondary forest succession (Fig. 9). Not surprisingly, the percentage of active agricultural land in pasture explained $24 \%$ of the among-district variation in gross agricultural income per hectare. Thus, it seems likely that pasture and cattle are being abandoned. A 
Table 1. Net change in the population between 1990 and 2000 and net change in forest cover between 1992 and 2000 for the Republic of Panama.

\begin{tabular}{lccc}
\hline \hline Variable & 1992 & 2000 & Rate of change $\left(\% \mathrm{yr}^{-1}\right)$ \\
\hline Population & $2,326,291 \dagger$ & $2,839,177$ & 2.0 \\
Agricultural land cover $\left(\mathrm{km}^{2}\right)$ & 20,894 & 18,979 & -1.2 \\
Total forest cover $\left(\mathrm{km}^{2}\right)$ & 52,528 & 54,074 & 0.36 \\
Mature forest cover $\left(\mathrm{km}^{2}\right)$ & 36,245 & 32,714 & -1.3 \\
Old secondary forest cover $\left(\mathrm{km}^{2}\right)$ & 7189 & 9935 & 4.1 \\
Young secondary forest cover $\left(\mathrm{km}^{2}\right)$ & 9094 & 11,425 & 2.9 \\
\hline
\end{tabular}

†Censused in 1990.

站efined as < 5 yr old; also called rastrojo in Panama.

comparison of national agricultural censuses from before 2000 might allow the evaluation of this hypothesis.

\section{The future of Panamanian forests}

We think that economics will determine the future of Panamanian forests. Today, the service, industrial, and agricultural sectors provide 77, 16.2, and just $6.8 \%$ of all economic activity, respectively (https://www.cia.gov/library/publications/the-worldfactbook/geos/pm.html). Panama City is the economic engine of Panama's service sector. Population growth averaged $3.6 \%$ in the home province of Panama City and $1.9 \%$ in the rest of the country from 1911 to 2000. The growth of the service sector fueled much of this population growth differential and has already prevented forest loss. Real economic growth averaged 4.1, 4.6, and 7.2\% annually for 1992-2000, 2000-2006, and in 2007, respectively, and the per capita gross domestic product expressed as purchasing power parity was US\$9000 in 2007. We speculate that this sustained economic growth has drawn workers from the agricultural sector (Fig. 4B) to better jobs mainly in Panama City. Still, the future of Panamanian forests is uncertain. Someone undoubtedly owns much of the lands that are now covered by secondary forests. The future actions of these owners will be critical.
As an example, a limited forest transition has occurred in Amazonian Ecuador as the rural poor changed their land management practices to swidden cycles that increase secondary forest cover, but hold little prospect for long-term forest regeneration (Rudel et al. 2002). This does not describe Panama, where adult children of farmers and often entire families migrate to urban centers. Many of these people are unlikely to return to their agricultural roots as long as there are jobs. There is reason to hope that the limited forest transition now underway in Panama will lead to long-term forest recovery.

Responses to this article can be read online at:

http://www.ecologyandsociety.org/vol13/iss2/art17/responses/

\section{Acknowledgments:}

We thank the Autoridad Nacional de Ambiente and the Controlaría for providing open access to landcover and census data for the Republic of Panama, Milton Solano for preparing figures 1 and 2, Mitch Aide and Ricardo Grau for organizing the symposium, and the National Science Foundation (DEB-0731594) for financial support. 


\section{LITERATURE CITED}

Aide, T. M., and H. R. Grau. 2004. Globalization, migration, and Latin American ecosystems. Science 305:1915-1916.

Baptista, S. R., and T. K. Rudel. 2006. A reemerging Atlantic forest? Urbanization, industrialization and the forest transition in Santa Catarina, southern Brazil. Environmental Conservation 33(3):195-202.

Food and Agriculture Organization. 2006. Global forest resources assessment 2005: progress towards sustainable forest management. FAO Forestry Paper 147. Food and Agriculture Organization, Rome, Italy. Available online at: http://www.fao.org/ DOCREP/008/a0400e/a0400e00.htm.

Garver, R. D. 1947. National survey of the forest resources of the Republic of Panama. State Department, Washington, D.C., USA.

Grau, H. R., M. E. Hernández, J. Gutierrez, N. I. Gasparri, M. C. Casavecchia, E. E. Flores, and L. Paolini. 2008. A peri-urban neotropical forest transition and its consequences for environmental services. Ecology and Society 13(1): 35. [online] URL: http://www.ecologyandsociety.org/vol13/iss1/ art35/.

Gutiérrez, R. 2005. Evaluación de los recursos forestales mundiales 2005: Panamá informe nacional. Food and Agriculture Organization, Rome, Italy.

Hecht, S. B., S. Kandel, I. Gomes, N. Cuellar, and H. Rosa. 2006. Globalization, forest resurgence, and environmental politics in El Salvador. World Development 34(2):308-323.

Heckadon Moreno, S. 1984. Panama's expanding cattle front: the Santeno campesinos and the colonization of the forests. Dissertation. University of Essex, Colchester, UK.

Holdridge, L. R., and G. Budowski. 1956. Report of an ecological survey of the Republic of Panama. Caribbean Forester 17:92-110.

Instituto de Investigación Agropecuaria de Panamá. 2006. Zonificacion de suelos de Panamÿ por niveles de nutrientes. Instituto de Investigación Agropecuaria de Panamá, Panama City, Panama. Available online at: http://www.idiap.gob.pa/zonifi cacion/ZONY.html.
Izquierdo, A. E., C. De Angelo, and T. M. Aide. 2008. Thirty years of human demography and landuse change in the Atlantic forest of Misiones, Argentina: a test of the forest transition model. Ecology and Society in press.

Jaén Suárez, O. 1981. Geografía de Panamá: estudio introductorio y antología. Universidad de Panamá, Panama City, Panama.

Kauppi, P. E., J. H. Ausubel, J. Fang, A. S. Mather, R. A. Sedjo, and P. E. Waggoner. 2006. Returning forests analyzed with the forest identity. Proceedings of the National Academy of Sciences 103(46):17574-17579.

Killeen, T. J., A. Guerra, M. Calzada, L. Correa, V. Calderon, L. Soria, B. Quezada, and M. K. Steininger. 2008. Total historical land-use change in eastern Bolivia: Who, where, when, and how much? Ecology and Society 13(1): 36. [online] URL: http://www.ecologyandsociety.org/vol13/iss 1/ $\underline{\operatorname{art} 36 / .}$.

Kleinn, C., L. Corrales, and D. Morales. 2002. Forest area in Costa Rica: a comparative study of tropical forest cover estimates over time. Environmental Monitoring and Assessment $\mathbf{7 3}$ (1):17-40.

Klooster, D. 2003. Forest transitions in Mexico: institutions and forests in a globalized countryside. Professional Geographer 55(2):227-237.

Lugo, A. E., and E. Helmer. 2004. Emerging forests on abandoned land: Puerto Rico's new forests. Forest Ecology and Management 190 (2-3):145-161.

Mather, A. S. 1992. The forest transition. Area 24 (4):367-379.

Meehl, G. A., T. F. Stocker, W. D. Collins, P. Friedlingstein, A. T. Gaye, J. M. Gregory, A. Kitoh, R. Knutti, J. M. Murphy, A. Noda, S. C. B. Raper, I. G. Watterson, A. J. Weaver, and Z.C. Zhao. 2007. Global climate projections. Pages 747-845 in S. Solomon, D. Qin, M. Manning, Z. Chen, M. Marquis, K. B. Averyt, M. Tignor, and H. L. Miller, editors. Climate change 2007: the physical science basis. Contribution of Working Group I to the Fourth Assessment Report of the Intergovernmental Panel on Climate Change. Cambridge University Press, Cambridge, UK. 
Millennium Ecosystem Assessment. 2005. Ecosystems and human well-being: biodiversity synthesis. World Resources Institute, Washington, D.C., USA. Available online at: http://www.millen niumassessment.org/en/index.aspx.

Neeff, T., R. M. Lucas, J. R. dos Santos, E. S. Brondizio, and C. C. Freitas. 2006. Area and age of secondary forests in Brazilian Amazonia 19782002: an empirical estimate. Ecosystems 9 (4):609-623.

Nelson, R. F., D. S. Kimes, W. A. Salas, and M. Routhier. 2000. Secondary forest age and tropical forest biomass estimation using thematic mapper imagery. Bioscience 50(5):419-431.

Parés-Ramos, I., W. A. Gould, and T. M. Aide. 2008. Suburban growth and forest expansion following agricultural abandonment in Puerto Rico (1991-2000). Ecology and Society 13(2): 1. [online] URL: http://www.ecologyandsociety.org/vol13/iss2/ $\underline{\operatorname{art} 1 /}$.

Perz, S. G., and D. L. Skole. 2003. Secondary forest expansion in the Brazilian Amazon and the refinement of forest transition theory. Society and Natural Resources 16(4):277-294.

Ramankutty, N., and J.A. Foley. 1999. Estimating historical changes in global land cover: croplands from 1700 to 1992. Global Biogeochemical Cycles 13(4):997-1027.

Rudel, T. K., D. Bates, and M. Machinguiashi. 2002. A tropical forest transition? Agricultural change, out-migration, and secondary forests in the Ecuadorian Amazon. Annals of the Association of American Geographers 92(1):87-102.

Rudel, T. K., O. T. Coomes, E. Moran, F. Achard, A. Angelsen, J. Xu, and E. Lambin. 2005. Forest transitions: towards a global understanding of land use change. Global Environmental Change 15 (1):23-31.

Sauer, C. O. 1966. The early Spanish Main. University of California Press, Berkeley, California, USA.

Schwerdtfeger, W., editor. 1976. Climates of Central and South America. Elsevier, Amsterdam, The Netherlands.
SYSTAT. 2004. SYSTAT 11.0. SYSTAT Software, Richmond, California, USA.

Wright, S. J., and H. C. Muller-Landau. 2006. The future of tropical forest species. Biotropica $\mathbf{3 8}$ (3):287-301. 
Appendix 1. Districts whose boundaries changed.

Please click here to download file 'appendix1.pdf'. 


\section{Appendix 2. Human poverty index}

\section{Please click here to download file 'appendix2.pdf'.}


Appendix 3. Land cover, population and agricultural data for the 76 districts that comprise Panama.

Please click here to download file 'appendix3.pdf'. 